\title{
Synthesis of Sequential Wholly Aromatic Polyketone Composed of 2,2'-Dimethoxybiphenylene Unit
}

\author{
Noriyuki Yonezawa, ${ }^{\dagger}$ Asami Kameda, Takashi Jobashi, Satoshi MaruYama, and Katsuya Maeyama \\ Department of Organic and Polymer Materials Chemistry, Tokyo University of Agriculture and Technology, \\ Koganei, Tokyo 184-8588, Japan
}

(Received January 6, 2004; Accepted February 2, 2004)

\begin{abstract}
Sequential wholly aromatic polyketone 5, where 2,2'-dimethoxybiphenylene units and $m, p$-diphenylenedicarbonyl ones align alternately, was successfully synthesized via finely tuned designings of the structure and synthetic protocol for arenecarboxylic acid monomer (6). Different from the 2,2'-dimethoxybiphenylene-containing wholly aromatic polyketones (1-4) reported recently, the polyketone (5), the conjugated macromolecule composed of regiochemically sequenced arene and carbonyl moieties, is soluble in organic solvents.

KEY WORDS Direct Polycondensation / $\mathrm{P}_{2} \mathrm{O}_{5}-\mathrm{CH}_{3} \mathrm{SO}_{3} \mathrm{H} /$ Sequential Wholly Aromatic Polyketone / Excellent Solubility /
\end{abstract}

Aromatic polyketones have attracted much attention for their excellent chemical and physical properties and there have been a lot of reports on the synthesis of aromatic polyketones. ${ }^{1-5}$ Nevertheless, almost all of aromatic polyketones are classified as aromatic poly(ether ketone)s, which contain ether linkages in the main chains. On the contrary, there have been only a few reports on wholly aromatic polyketones, i.e., aromatic polyketones without ether linkages in the main chains except for our study. ${ }^{6-9}$

For the synthesis of wholly aromatic polyketones, electrophilic aromatic substitution such as FriedelCrafts acylation and aromatic coupling reaction are presumed to be the choices. In connection with the synthesis of wholly aromatic polyketones, we have previously reported that $\mathrm{AlCl}_{3}$-mediated FriedelCrafts type acylation polymerization of 2,2'-dimethoxybiphenyl with arenedicarbonyl chloride readily affords wholly aromatic polyketones. ${ }^{10,11}$ The sterically and electrically characteristic structure of 2,2'-dimethoxybiphenyl makes itself to be an excellent acyl-acceptant monomer for electrophilic aromatic substitution polymerization. The resulting polyketones (1 and $\mathbf{2})$ are regioisomers to each other: phenylene units are connected at p-positions in polyketone $\mathbf{1}$ and at $m$-positions in polyketone 2 . These polyketones show good heat-resistibility. At the same time, they have high solvent-resistibility and they are insoluble in organic solvents.

We have also synthesized wholly aromatic polyketones containing 2,2'-dimethoxybiphenylene unit and biphenylenedicarbonyl one via nickel complex-mediated aromatic homocoupling polymerization. ${ }^{12,13}$ The obtained polyketones ( $\mathbf{3}$ and $\mathbf{4}$ ) consist of symmetrical biphenylenedicarbonyl units. And, the isotropic se- quence of these polymers probably makes the polymer main chain rigid. As an attempt to achieve disordered sequence of the polymer chain, nickel complex-mediated copolymerization of symmetrically bis(chlorobenzoylated) 2,2'-dimethoxybiphenyls was also undertaken. ${ }^{14}$ Furthermore, introduction of unsymmetrical biphenylenedicarbonyl unit, i.e., $m, p$-biphenylenedicarbonyl unit, to wholly aromatic polyketone backbone was also undertaken. ${ }^{15}$ On the other hand, from the point of the synthesis of $\mathrm{C}\left(\mathrm{sp}^{2}\right)-\mathrm{C}\left(\mathrm{sp}^{2}\right)$ macromolecular conjugated system composed of phenylene units and ketonic carbonyl groups, control of the sequence of regiochemistry is of great importance. In consequence of the above synthetic studies, the synthesis of sequential wholly aromatic polyketone (5), where 2,2'-dimethoxybiphenylene unit and $m, p$-biphenylenedicarbonyl one align alternately, was planned. The structure of the conjugated macromolecule composed of regiochemically sequenced phenylene and carbonyl moieties is of interest from the viewpoint of polymer synthetic chemistry. As a natural consequence for performance of such synthesis, finely tuned designings of the structure and synthetic protocol for the monomer is required.

In this paper, we would like to report the synthesis of the fine-tuned unimolecular monomer (6) and its successful polymerization to give the sequential wholly aromatic polyketone (5).

\section{EXPERIMENTAL}

\section{General}

All reactions were performed under nitrogen atmosphere. ${ }^{1} \mathrm{HNMR}$ spectra were recorded on a JEOL JNM-FX200 (200 MHz). Chemical shifts are ex-

${ }^{\dagger}$ To whom correspondence should be addressed (Tel: +81-42-388-7053, Fax: +81-42-381-7979, E-mail: yonezawa@cc.tuat.ac.jp). 
<smiles>COc1cccc(-c2cc(C(=O)c3ccc(C(=O)C(C)C)cc3)ccc2OC)c1</smiles>

1<smiles>COc1cccc(C(=O)c2cccc(C(=O)c3ccc(OC)c(C)c3)c2)c1</smiles>

2

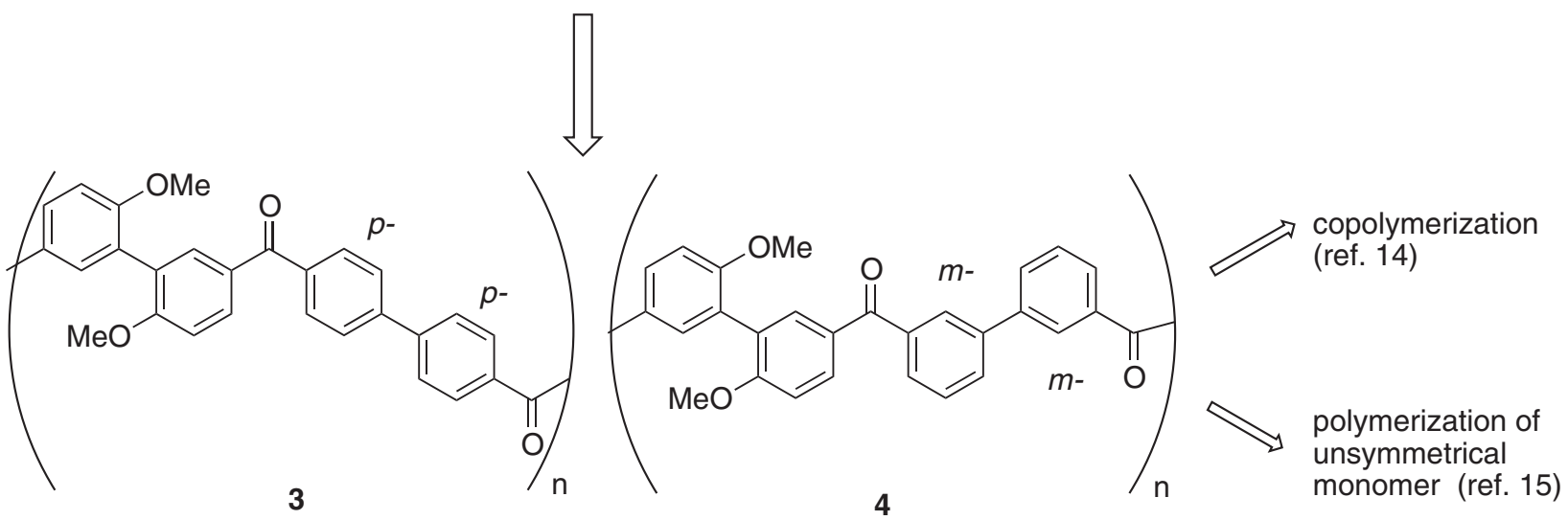<smiles>COc1ccccc1-c1cc(C(=O)c2cccc(-c3ccc(C(=O)c4cccc(-c5cccc(OC)c5-c5cc(C(=O)O)ccc5OC)c4)cc3)c2)ccc1OC</smiles>

Scheme 1.

pressed in ppm relative to internal standard of $\mathrm{Me}_{4} \mathrm{Si}$ $(\delta, 0.00) .{ }^{13} \mathrm{C}$ NMR spectra were recorded on a JEOL JNM-A500 (125 MHz). Chemical shifts are expressed in ppm relative to internal standard of $\mathrm{CDCl}_{3}(\delta, 77.0)$. IR measurements were recorded on a JEOL FT/IR5300.

Gel permeation chromatography (GPC) measurement was carried out on a Shimadzu SPD-6A equipped with a UV detector $(300 \mathrm{~nm})$ and a Shodex GPC $\mathrm{KD}-806 \mathrm{M}$ column at a flow rate of $1.0 \mathrm{~mL} \mathrm{~min}^{-1}$ at $40{ }^{\circ} \mathrm{C}$ using $\mathrm{CHCl}_{3}$ as an eluent. Inherent viscosities $\left(\eta_{\text {inh }}\right)$ were determined in a concentrated $\mathrm{H}_{2} \mathrm{SO}_{4}$ $\left(0.3 \mathrm{~g} \mathrm{dL}^{-1}\right)$ solution at $30^{\circ} \mathrm{C}$ using an Ostwald viscometer. Glass transition temperature $\left(T_{\mathrm{g}}\right)$ was determined on the basis of a DSC curve. The DSC curve was recorded on a SEIKO DSC-200 differential scanning calorimeter with a heating rate of $10 \mathrm{~K} \mathrm{~min}^{-1}$ under nitrogen. Thermal degradation temperature $\left(T_{\mathrm{d}}\right)$ was determined on the basis of a TGA thermogram. The TGA thermogram was recorded on a SEIKO TG/DTA-200 thermogravimeter with a heating rate of $10 \mathrm{~K} \mathrm{~min}^{-1}$.

$\mathrm{P}_{2} \mathrm{O}_{5}-\mathrm{CH}_{3} \mathrm{SO}_{3} \mathrm{H}(\mathrm{MsOH})$ was prepared according to Eaton's procedure. ${ }^{16}$

\section{3-Bromo-3'-iodo-4-methoxybenzophenone (7)}

$o$-Bromoanisole $(1.88 \mathrm{~g}, 10 \mathrm{mmol})$ and $m$-iodobenzoic acid $(2.48 \mathrm{~g}, 10 \mathrm{mmol})$ were dissolved to $10 \mathrm{~mL}$ of $\mathrm{P}_{2} \mathrm{O}_{5}-\mathrm{MsOH}$ in a three-necked flask equipped with a reflux condenser. The mixture was stirred at $80^{\circ} \mathrm{C}$ for $2 \mathrm{~h}$. The reaction was quenched with water and the resulting aqueous mixture was extracted with chloroform. The organic extracts were washed with aqueous $0.1 \mathrm{M}$ sodium hydroxide and brine in turn and dried over magnesium sulfate. After removal of solvent, the residue was purified by recrystallization from ethanol to give pure phenone 7 in a $64 \%$ yield. IR $v$ (KBr): $1649,583 \mathrm{~cm}^{-1} .{ }^{1} \mathrm{H} \mathrm{NMR}(200 \mathrm{MHz}) \delta$ $\left(\mathrm{CDCl}_{3}\right): 3.99(3 \mathrm{H}, \mathrm{s}), 6.97(1 \mathrm{H}, \mathrm{d}, J=8 \mathrm{~Hz}), 7.23$ $(1 \mathrm{H}, \mathrm{t}, J=8 \mathrm{~Hz}), 7.64-7.69(1 \mathrm{H}, \mathrm{m}), 7.75(1 \mathrm{H}, \mathrm{dd}$, $J=2,8 \mathrm{~Hz}), 7.88-7.93(1 \mathrm{H}, \mathrm{m}), 8.05-8.08(2 \mathrm{H}, \mathrm{m})$ ppm. ${ }^{13} \mathrm{CNMR}(125 \mathrm{MHz}) \delta\left(\mathrm{CDCl}_{3}\right): 56.5,94.1$, 
$111.0,111.9,123.7,129.9,130.5,131.5,135.3,138.2$, 139.5, 141.0, 159.5, $192.6 \mathrm{ppm}$. Anal. Calcd. for $\mathrm{C}_{14} \mathrm{H}_{10} \mathrm{BrIO}_{2}$ : C, $40.32 \%$; $\mathrm{H}, 2.42 \%$. Found: $\mathrm{C}$, $40.24 \%$; H, $2.52 \%$.

\section{3-Bromo-3'-(4-cyanophenyl)-4-methoxybenzophenone} (8)

3-Bromo-3'-iodo-4-methoxybenzophenone (7, 4.17 $\mathrm{g}, 10 \mathrm{mmol})$, 4-cyanophenylboric acid $(1.60 \mathrm{~g}, 11$ $\mathrm{mmol}$ ), and tetrakis(triphenylphosphine)palladium $(0)$ $(0.58 \mathrm{~g}, 0.50 \mathrm{mmol})$ were placed in a three-necked flask equipped with a reflux condenser. To this flask, $20 \mathrm{~mL}$ of toluene, $5 \mathrm{~mL}$ of ethanol, and $5 \mathrm{~mL}$ of aqueous $2 \mathrm{M}$ sodium carbonate were introduced. The mixture was stirred under reflux for $24 \mathrm{~h}$. The reaction was quenched with water and the resulting aqueous mixture was extracted with chloroform. The combined organic extracts were washed with brine twice and dried over sodium sulfate. After removal of solvent, the residue was purified by column chromatography (hexane: ethyl acetate $=1: 1$ ) to give phenone $\mathbf{8}$ in a $92 \%$ yield. IR $v(\mathrm{KBr}): 2841,2228,1649,565 \mathrm{~cm}^{-1}$. ${ }^{1} \mathrm{H}$ NMR $(200 \mathrm{MHz}) \delta\left(\mathrm{CDCl}_{3}\right): 4.00(3 \mathrm{H}, \mathrm{s}), 7.00(1 \mathrm{H}, \mathrm{d}, J=$ $8 \mathrm{~Hz}), 7.61(1 \mathrm{H}, \mathrm{t}, J=8 \mathrm{~Hz}), 7.73-7.85(7 \mathrm{H}, \mathrm{m}), 7.98$ $(1 \mathrm{H}, \mathrm{t}, J=2 \mathrm{~Hz}), 8.10(1 \mathrm{H}, \mathrm{d}, J=2 \mathrm{~Hz}) \mathrm{ppm} .{ }^{13} \mathrm{C}$ NMR $(125 \mathrm{MHz}) \delta\left(\mathrm{CDCl}_{3}\right): 56.5,111.0,111.5$, $111.8,118.5,127.8,128.2,129.1,129.7,130.8$, $131.4,132.7,135.4,138.5,139.5,144.4,159.5$, $193.7 \mathrm{ppm}$. Anal. Calcd. for $\mathrm{C}_{21} \mathrm{H}_{14} \mathrm{BrNO}_{2}: \mathrm{C}$, $64.30 \%$; H, 3.60\%; N, 3.57\%. Found: C, 64.29\%; H, $3.73 \% ; \mathrm{N}, 3.37 \%$.

3'-(4-Cyanophenyl)-4-methoxy-3-(2-methoxyphenyl)benzophenone (9)

3-Bromo-3'-(4-cyanophenyl)-4-methoxybenzophenone $(8,2.10 \mathrm{~g}, 5.35 \mathrm{mmol}), 2$-methoxyphenylboric acid $(1.63 \mathrm{~g}, \quad 10.7 \mathrm{mmol})$, tetrakis(triphenylphosphine)palladium $(0)(0.31 \mathrm{~g}, 0.28 \mathrm{mmol})$ were placed in a three-necked flask equipped with a reflux condenser. To this flask, $10.7 \mathrm{~mL}$ of toluene, $2.8 \mathrm{~mL}$ of ethanol, and $2.8 \mathrm{~mL}$ of aqueous $2 \mathrm{M}$ sodium carbonate were added further. The mixture was stirred at $80^{\circ} \mathrm{C}$ for $2 \mathrm{~h}$. The reaction was quenched with water and the resulting aqueous mixture was extracted with chloroform. The combined organic extracts were washed with brine twice and dried over sodium sulfate. After removal of solvent, the residue was purified by column chromatography (hexane: ethyl acetate $=$ $2: 1 \mathrm{v} / \mathrm{v}$ ) to give pure phenone 9 in a $98 \%$ yield.

IR $v$ (KBr): $2225,1651 \mathrm{~cm}^{-1}$. ${ }^{1} \mathrm{HNMR}(200 \mathrm{MHz}) \delta$ $\left(\mathrm{CDCl}_{3}\right): 3.73(3 \mathrm{H}, \mathrm{s}), 3.89(3 \mathrm{H}, \mathrm{s}), 6.97(1 \mathrm{H}, \mathrm{d}$, $J=8 \mathrm{~Hz}), 7.01(1 \mathrm{H}, \mathrm{t}, J=8 \mathrm{~Hz}), 7.06(1 \mathrm{H}, \mathrm{d}, J=$ $8 \mathrm{~Hz}), 7.24(1 \mathrm{H}, \mathrm{t}, J=2 \mathrm{~Hz}), 7.34(1 \mathrm{H}, \mathrm{t}, J=8 \mathrm{~Hz})$, $7.58(1 \mathrm{H}, \mathrm{t}, J=8 \mathrm{~Hz}), 7.71(2 \mathrm{H}, \mathrm{dd}, J=2,8 \mathrm{~Hz})$, $7.74(2 \mathrm{H}, \mathrm{dd}, J=2,8 \mathrm{~Hz}), 7.77(1 \mathrm{H}, \mathrm{d}, J=8 \mathrm{~Hz})$,
$7.81(1 \mathrm{H}, \mathrm{d}, J=2 \mathrm{~Hz}), 7.84(1 \mathrm{H}, \mathrm{d}, J=8 \mathrm{~Hz}), 7.92$ $(2 \mathrm{H}, \mathrm{dd}, J=2,8 \mathrm{~Hz}), 8.02(1 \mathrm{H}, \mathrm{t}, J=2 \mathrm{~Hz}) \mathrm{ppm}$. ${ }^{13} \mathrm{CNMR}(125 \mathrm{MHz}) \delta\left(\mathrm{CDCl}_{3}\right): 55.5,55.8,110.4$, $111.0,113.0,118.7,120.3,126.3,127.5,127.8$, $128.3,128.9,129.1,129.2,129.9,130.3,131.3$, $131.8,132.6,134.2,139.2,139.2,144.7,156.8$, 160.9, $194.5 \mathrm{ppm}$. Anal. Calcd. for $\mathrm{C}_{28} \mathrm{H}_{21} \mathrm{NO}_{3}$ : C, $80.17 \%$; H, 5.05\%; N, 3.34\%. Found: C, 79.89\%; H, $5.17 \% ; \mathrm{N}, 3.25 \%$.

\section{Carboxylic Acid 6}

3'-(4-Cyanophenyl)-4-methoxy-3-(2-methoxyphenyl)benzophenone $(9,1.34 \mathrm{~g}, 3.2 \mathrm{mmol}), 32 \mathrm{~mL}$ of ethanol, and $32 \mathrm{~mL}$ of aqueous $10 \mathrm{M}$ potassium hydroxide were added to a three-necked flask equipped with a reflux condenser. The mixture was stirred at $80^{\circ} \mathrm{C}$ for $24 \mathrm{~h}$. The reaction was quenched with water and the resulting aqueous mixture was acidified by addition of aqueous $\mathrm{HCl}$. The mixture was extracted with ether three times. The combined extracts were washed with brine twice and dried over sodium sulfate. After removal of solvent, the residue was purified by recrystallization from acetone to give pure carboxylic acid 6 in an $80 \%$ yield.

IR $v(\mathrm{KBr}): 1653,1255 \mathrm{~cm}^{-1}$. ${ }^{1} \mathrm{H}$ NMR $(200 \mathrm{MHz}) \delta$ $\left(\mathrm{CDCl}_{3}\right): 3.72(3 \mathrm{H}, \mathrm{s}), 3.87(3 \mathrm{H}, \mathrm{s}), 6.96(1 \mathrm{H}, \mathrm{d}$, $J=8 \mathrm{~Hz}), 7.01(1 \mathrm{H}, \mathrm{t}, J=8 \mathrm{~Hz}), 7.07(1 \mathrm{H}, \mathrm{d}, J=$ $8 \mathrm{~Hz}), 7.25(1 \mathrm{H}, \mathrm{dd}, J=2,8 \mathrm{~Hz}), 7.35(1 \mathrm{H}, \mathrm{dt}, J=$ $2,8 \mathrm{~Hz}), 7.57(1 \mathrm{H}, \mathrm{t}, J=8 \mathrm{~Hz}), 7.72(2 \mathrm{H}, \mathrm{d}, J=$ $8 \mathrm{~Hz}), 7.77-7.85(3 \mathrm{H}, \mathrm{m}), 7.92(1 \mathrm{H}, \mathrm{dd}, J=2$, $8 \mathrm{~Hz}), 8.07(1 \mathrm{H}, \mathrm{d}, J=2 \mathrm{~Hz}), 8.20(2 \mathrm{H}, \mathrm{d}, J=$ $8 \mathrm{~Hz})$ ppm. ${ }^{13} \mathrm{CNMR}(125 \mathrm{MHz}) \delta\left(\mathrm{CDCl}_{3}\right): 55.6$, 56.1, 111.4, 111.6, 120.4, 126.2, 127.3, 127.4, 127.7, $128.7,129.3,129.4,129.5,130.2,130.3,130.7$, $131.2,131.9,133.4,138.8,139.4,143.6,156.8$, 160.9, 167.3, 194.4 ppm. Anal. Calcd. for $\mathrm{C}_{28} \mathrm{H}_{22} \mathrm{O}_{5}$ : C, $76.70 \%$; H, 5.06\%. Found: C, 76.85\%; H, 5.08\%.

\section{Direct Condensation Polymerization of Carboxylic Acid 6}

Carboxylic acid $6(43.9 \mathrm{mg}, 0.1 \mathrm{mmol})$ was dissolved in $2 \mathrm{~mL}$ of $\mathrm{P}_{2} \mathrm{O}_{5}-\mathrm{MsOH}$. The mixture was stirred at $60{ }^{\circ} \mathrm{C}$ for $3 \mathrm{~h}$. After dilution with $1 \mathrm{~mL}$ of $\mathrm{MsOH}$, the mixture was poured into $30 \mathrm{~mL}$ of methanol to separate out orange precipitates. The precipitates were collected by suction filtration and dried in vacuo at $100{ }^{\circ} \mathrm{C}$ to give an orange solid of polymer 5 . IR $v$ (KBr): $1649,1256 \mathrm{~cm}^{-1} .{ }^{1} \mathrm{H}$ NMR $(200 \mathrm{MHz}) \delta$ $\left(\mathrm{CDCl}_{3}\right): 3.79(3 \mathrm{H}, \mathrm{s}), 3.87(3 \mathrm{H}, \mathrm{s}), 7.01(1 \mathrm{H}, \mathrm{d}$, $J=5 \mathrm{~Hz}), 7.05(1 \mathrm{H}, \mathrm{d}, J=5 \mathrm{~Hz}), 7.55(1 \mathrm{H}, \mathrm{t}, J=$ $8 \mathrm{~Hz}), 7.69(2 \mathrm{H}, \mathrm{d}, J=8 \mathrm{~Hz}), 7.75-7.95(8 \mathrm{H}, \mathrm{m})$, $8.05(1 \mathrm{H}, \mathrm{s}) \mathrm{ppm} .{ }^{13} \mathrm{C} \mathrm{NMR}(125 \mathrm{MHz}) \delta\left(\mathrm{CDCl}_{3}\right)$ : $55.8,55.9,110.4,110.5,126.2,126.3,127.0,128.4$, $128.8,129.4,129.4,129.6,130.5,130.6,132.2$, $132.3,134.0,134.1,137.7,138.9,140.2,143.7$, 
160.6, 160.7, 194.8, $195.1 \mathrm{ppm}$. Anal. Calc. for $\left(\mathrm{C}_{28} \mathrm{H}_{20} \mathrm{O}_{4}\right)_{n}$ : C, $79.99 \%$; $\mathrm{H}, 4.79 \%$. Found: $\mathrm{C}$, $79.67 \%$; H, $5.08 \%$.

\section{RESULTS AND DISCUSSION}

As the synthetic pathway of sequential polyketone $\mathbf{5}$, we selected the approach of polymerization of unimolecular monomer $\mathbf{6}$. The monomer (6) has both an acyl-accepting unit and an acyl donating unit, i.e., 2,2'-dimethoxybiphenyl and arenecarboxy group, at each other side of the molecule. In this molecule, an acylium ion electrophile attacks only to the $p$ position against the methoxy group substituted on the outer phenyl group, which is the sole acyl-acceptable position among the electrically activated aromatic carbons on the basis of steric hindrance. All of the other positions in this molecule are sufficiently deactivated electrically and/or sterically. Consequently, the synthesis of unimolecular monomer $\mathbf{6}$ is critical for the synthesis of sequential wholly aromatic polyketone 5.

For sequential alignment of the unsymmetrical unit in polymer skeleton, monomer synthesis via stepwise cross-coupling reactions of 3-bromo-3'-iodo-4-methoxybenzophenone (7), i.e., the first coupling reaction at $3^{\prime}$-position and the second coupling reaction at 3-position, was subjected. The regioselective cross-coupling reaction has been successful by the control of reaction temperature and the selection of the kinds of base.

\section{Synthesis of Carboxylic Acid Monomer 6}

For the synthesis of monomer $\mathbf{6}$, dual arylations of a dihalobenzophenone derivative have been planned. As Suzuki cross-coupling reaction is facile ${ }^{17}$ to handle and effective for the synthesis of unsymmetrical biaryl compounds, this protocol was applied to the discriminative stepwise dual arylations of dihalobenzophenone having different leaving groups, i.e., bromo and iodo groups.

Two approaches are plausible for the synthesis of monomer $\mathbf{6}$ as shown in Scheme 2. One is via dual arylation of phenone $\mathbf{7}$ and the other is via that of phenone 10. For the synthetic performance of monomer 6, remarkable difference of reactivity be-<smiles>COc1ccccc1-c1cc(C(=O)c2cccc(-c3ccc(C(=O)O)cc3)c2)ccc1OC</smiles>

6<smiles>[2H]c1cc(C(=O)c2cccc(CC=C)c2)ccc1OC</smiles><smiles>C=C=C</smiles><smiles>COc1ccc(C(=O)c2cccc(C(C)(C)C)c2)cc1Br</smiles>

8<smiles>C=CC=C</smiles><smiles>COc1ccc(C(=O)c2cccc(I)c2)cc1Br</smiles>

7<smiles>COc1ccccc1[Te]c1cc(C(=O)c2cccc(Br)c2)ccc1OC</smiles>

11<smiles>[CH]=C</smiles><smiles>COc1ccc(C(=O)c2cccc(Br)c2)cc1I</smiles>

Scheme 2. 


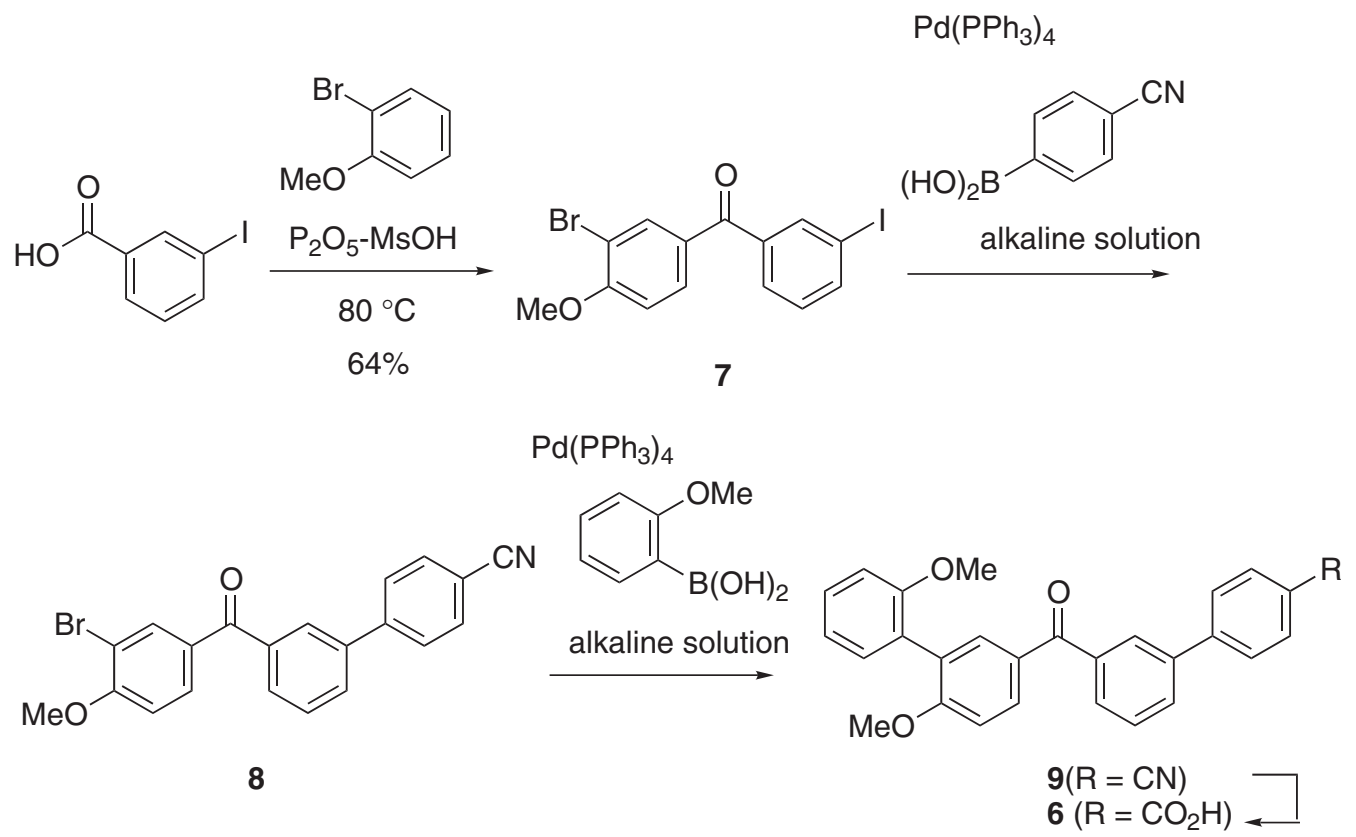

Scheme 3.

tween 3- and $3^{\prime}$-positions is required. Considering the difference between the reactivity at 3-position and that of $3^{\prime}$-position, phenone 7 is apparently favorable than phenone 10 on the ground of steric hindrance. Therefore, the route via phenone 7 was examined (Scheme 3).

Phenone 7 was prepared via $\mathrm{P}_{2} \mathrm{O}_{5}-\mathrm{MsOH}$ mediated direct condensation of 3-iodobenzoic acid with 2-bromoanisole in a $64 \%$ yield. The first Suzuki-coupling reaction of phenone 7 with 4-cyanophenylboric acid was performed in benzene in the presence of $\mathrm{Pd}\left(\mathrm{PPh}_{3}\right)_{4}$ and sodium carbonate. Elongation of reaction time to $48 \mathrm{~h}$ and use of toluene as a solvent instead of benzene afforded the cyanophenyl-substituted benzophenone (8) in a higher yield.

The second arylation via cross-coupling reaction showed lower reactivity than the first one. To realize this arylation, more severe reaction conditions were employed. As a result, use of 2 equimolar amounts of anisylboric acid, $\mathrm{K}_{2} \mathrm{CO}_{3}$ instead of $\mathrm{Na}_{2} \mathrm{CO}_{3}$ as a base, and use of $5 \mathrm{~mol} \%$ catalyst have improved the yield of monomer precursor 9 up to $98 \%$ yield.

Conversion of nitrile 9 to carboxylic acid $\mathbf{6}$ was attempted under reflux in the mixed solvents of aqueous $10 \mathrm{M}$ sodium hydroxide and ethanol for $24 \mathrm{~h}$, resulting in failure of hydrolysis. When aqueous $10 \mathrm{M}$ potassium hydroxide was used instead, hydrolysis of nitrile 9 proceeded to give carboxylic acid $\mathbf{6}$ in a good yield. As an alternate transformation route, stepwise hydrolysis, i.e., conversion of nitrile 9 to amide $\mathbf{9}^{\prime}$ followed by hydrolysis in aqueous $10 \mathrm{M}$ potassium hydroxide, also afforded carboxylic acid 6, however, without improvement of reaction efficiency.
Table I. Cross-coupling reaction of phenone 7 with 4-cyanophenylboric acid

\begin{tabular}{cclccr}
\hline \multirow{2}{*}{ Run } & Amount of & Solvent & Time & \multicolumn{2}{c}{ Yield (\%) } \\
& catalyst & & (h) & $\mathbf{8}$ & $\mathbf{7}$ \\
\hline 1 & $3 \mathrm{~mol} \%$ & benzene & 24 & 64 & 25 \\
2 & $5 \mathrm{~mol} \%$ & toluene & 24 & 72 & 16 \\
3 & $5 \mathrm{~mol} \%$ & toluene & 48 & 92 & 0 \\
\hline
\end{tabular}

Reaction conditions: phenone 7,10 mmol; 4-cyanophenylboric acid, $11 \mathrm{mmol}$; Catalyst, $\mathrm{Pd}\left(\mathrm{PPh}_{3}\right)_{4}$; EtOH, $5 \mathrm{~mL}$; benzene/toluene, $20 \mathrm{~mL}$; aqueous $2 \mathrm{M} \mathrm{Na}_{2} \mathrm{CO}_{3}$ solution, $5 \mathrm{~mL}$. $\mathrm{N}_{2}$ atmosphere.

Table II. Cross-coupling reaction of phenone 8 with $o$-anisylboric acid

\begin{tabular}{cclc}
\hline Run & Catalyst & \multicolumn{1}{c}{$\begin{array}{c}\text { Alkaline } \\
\text { solution }\end{array}$} & $\begin{array}{c}\text { Yield } \\
(\%)\end{array}$ \\
\hline 1 & $3 \mathrm{~mol} \%$ & $\mathrm{Na}_{2} \mathrm{CO}_{3}$ aq. & 45 \\
2 & $3 \mathrm{~mol} \%$ & $\mathrm{~K}_{2} \mathrm{CO}_{3}$ aq. & 60 \\
3 & $5 \mathrm{~mol} \%$ & $\mathrm{~K}_{2} \mathrm{CO}_{3}$ aq. & 98 \\
\hline
\end{tabular}

Reaction conditions: phenone $\mathbf{8}, 5.35 \mathrm{mmol}$; $o$-anisylboric acid, $10.7 \mathrm{mmol}$; Catalyst, $\mathrm{Pd}\left(\mathrm{PPh}_{3}\right)_{4}$; EtOH, $2.8 \mathrm{~mL}$; toluene, $10.7 \mathrm{~mL}$; aqueous $2 \mathrm{M} \mathrm{Na}_{2} \mathrm{CO}_{3} / \mathrm{K}_{2} \mathrm{CO}_{3}$ solution, $2.8 \mathrm{~mL}$; reflux, $24 \mathrm{~h}, \mathrm{~N}_{2}$ atmosphere.

\section{Direct Condensation of Carboxylic Acid 6}

$\mathrm{P}_{2} \mathrm{O}_{5}-\mathrm{MsOH}$ mediated direct condensation polymerization $^{18-21}$ of monomer 6 readily proceeded to give high-molecular-weight polyketone. The formation of the polyketone is confirmed on the basis of ${ }^{1} \mathrm{HNMR}$ and IR spectra. In the ${ }^{1} \mathrm{HNMR}$ spectrum of the product, the signal at $8.20 \mathrm{ppm}$ of monomer $\mathbf{6}$, 
Table III. Conversion of nitrile 9 into carboxylic acid $\mathbf{6}$

\begin{tabular}{clc}
\hline Run & Alkaline solution & $\begin{array}{c}\text { Yield } \\
(\%)\end{array}$ \\
\hline 1 & $10 \mathrm{M} \mathrm{NaOH}_{\text {aq. }}$ & 0 \\
2 & $10 \mathrm{M} \mathrm{KOH}_{\text {aq. }}$ & 80 \\
$3^{\text {a }}$ & $10 \mathrm{M} \mathrm{KOH}_{\text {aq. }}$ & 76 \\
\hline
\end{tabular}

Reaction conditions: nitrile 9, $3.2 \mathrm{mmol}$; EtOH, $32 \mathrm{~mL}$; aqueous $10 \mathrm{M} \mathrm{Na} \mathrm{CO}_{3} / \mathrm{K}_{2} \mathrm{CO}_{3}$ solution, $32 \mathrm{~mL} .80^{\circ} \mathrm{C}, 24 \mathrm{~h}, \mathrm{~N}_{2}$ atmospher

${ }^{\text {a Amide }} \mathbf{9}^{\prime}$ was employed instead of nitrile $\mathbf{9}$.

which is assignable to the ortho proton of carboxy group, disappears and a new signal at $7.85 \mathrm{ppm}$ appears. This indicates that the carboxy group is transformed into a ketonic carbonyl one. The triplet signal at $7.01 \mathrm{ppm}$ of monomer $\mathbf{6}$, which is assignable to the $p$-positioned proton of the outer methoxy group, disappears in that of the product. It means bond formation occurs at the $p$-position of the outer methoxy group. In addition, a carbonyl peak at $1680 \mathrm{~cm}^{-1}$ in IR spectrum of monomer $\mathbf{6}$, which is assignable to the stretching vibration of carbon-oxygen double bond of carboxylic acid, disappears in that of the product. The results of optimization of reaction conditions are shown in Table IV.

The optimized reaction temperature is $60^{\circ} \mathrm{C}$ and the optimized monomer concentration is $2 \mathrm{~mol} / \mathrm{L}$. The polyketones obtained in Runs 2 and 6 are cast from chloroform to give transparent orange films. The others show no film forming ability, whose degrees of polymerization are estimated considerably smaller than those of polyketones obtained in Runs 2 and 6. The number-average molecular weight $\left(M_{\mathrm{n}}\right)$ of the

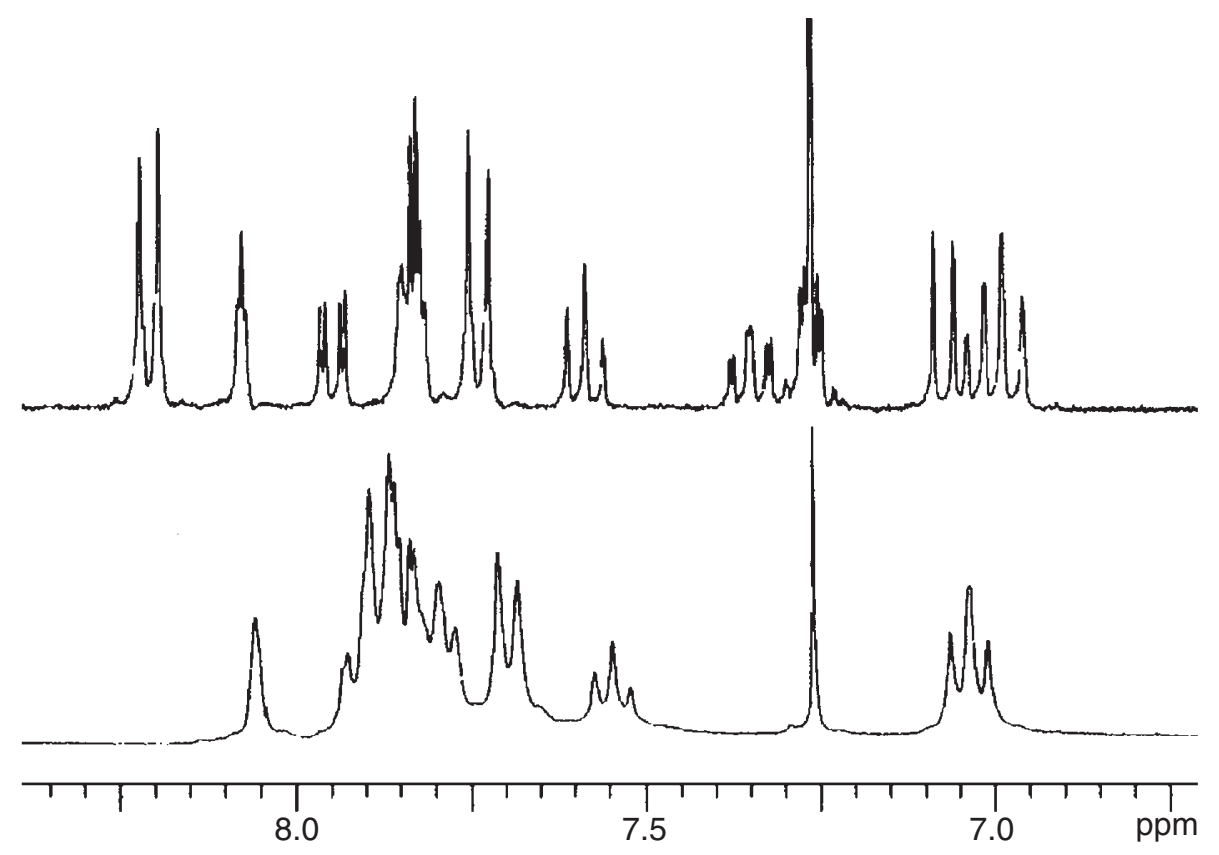

Figure 1. ${ }^{1}$ H NMR spectra of monomer 6 (upper) and polyketone 5 (lower)<smiles>COc1ccccc1-c1cc(C(=O)c2cccc(-c3ccc(C(=O)O)cc3)c2)ccc1OC</smiles>

6

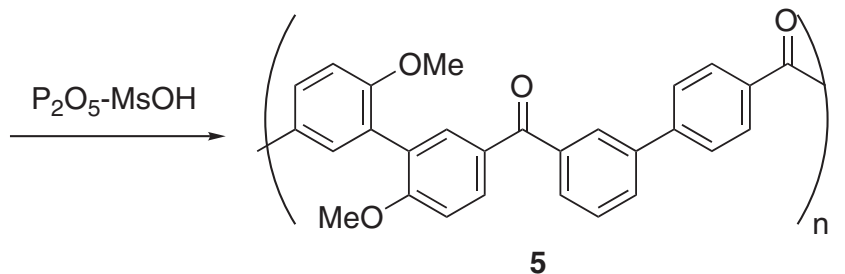

Scheme 4. 
Table IV. Direct polycondensation of carboxylic acid 6

\begin{tabular}{cccccc}
\hline Run & $\begin{array}{c}\text { Temp. } \\
\left({ }^{\circ} \mathrm{C}\right)\end{array}$ & $\begin{array}{c}\mathrm{P}_{2} \mathrm{O}_{5}-\mathrm{MsOH} \\
(\mathrm{mL})\end{array}$ & $\begin{array}{c}\text { Yield } \\
(\%)\end{array}$ & $\begin{array}{c}\eta_{\text {inh }}{ }^{\mathrm{a}} \\
\left(\mathrm{dL}^{-1}\right)\end{array}$ & Film $^{\mathrm{b}}$ \\
\hline 1 & 30 & 0.2 & 73 & 0.15 & - \\
2 & 60 & 0.2 & 79 & 0.40 & + \\
3 & 90 & 0.2 & 71 & 0.34 & - \\
4 & 120 & 0.2 & 89 & 0.12 & - \\
5 & 60 & 0.1 & 81 & 0.12 & - \\
6 & 60 & 0.4 & 98 & 0.30 & + \\
\hline
\end{tabular}

Reaction conditions: carboxylic acid $\mathbf{6}, 0.1 \mathrm{mmol}, \mathrm{N}_{2}$ atmosphere.

${ }^{\text {a }}$ Determined in a concentrated $\mathrm{H}_{2} \mathrm{SO}_{4}$ solution $\left(0.3 \mathrm{~g} \mathrm{dL}^{-1}\right)$ at $30^{\circ} \mathrm{C}$. ${ }^{\mathrm{b}}+$, flexible film was formed by cast from $\mathrm{CHCl}_{3}$; no film was obtained.

polyketone obtained in Run 2 is estimated to be 9700 by GPC measurement $\left(M_{\mathrm{w}} / M_{\mathrm{n}}=3.62\right)$. When the polymerization was carried out at higher temperature, decrease in inherent viscosity was observed. Side reactions such as methanesulfonation probably occur, resulting in termination of acylation polymerization. The resulting polyketone shows good thermal properties. DSC measurement shows the $T_{\mathrm{g}}$ of polyketone $\mathbf{5}$ is $222^{\circ} \mathrm{C}$. The temperature is almost equal to that of polyketone $3,{ }^{13}$ which has $p, p$-biphenylene dicarbonyl unit. In addition, the polyketone (5) holds a weight up to $450^{\circ} \mathrm{C}$ and it began to decompose at this temperature as same as the polyketones (1-4) containing 2,2'dimethoxybiphenylene backbone.

\section{CONCLUSIONS}

By the aid of fine designings of the structure and the synthetic protocol of the unimolecular monomer, carboxylic acid $\mathbf{6}$, the wholly aromatic polyketone (5), where 2,2'-dimethoxybiphenylene unit and $m, p$-biphenylenedicarbonyl unit align alternately, was successfully synthesized via direct condensation of carboxylic acid $\mathbf{6}$. The polyketone (5) has a sufficient degree of polymerization, high heat-resistibility, and excellent solubility to organic solvents.

Acknowledgment. This work was partly supported by Casio Science Promotion Foundation.

\section{REFERENCES}

1. T. E. Attwood, P. C. Dawson, J. L. Freeman, L. R. J. Hoy, J. B. Rose, and P. A. Staniland, Polymer, 22, 1096 (1981).

2. M. J. Mullins and E. P. Woo, J. Macromol. Sci. Rev., Part C: Macromol. Chem. Phys., 27, 313 (1987).

3. P. A. Staniland, G. C. Eastmond, A. Ledwith, S. Russo, and P. Sigwalt, Ed., "Comprehensive Polymer Science," Vol 5, Pergamon Press, Oxford, 1989, p 483.

4. N. Yonezawa, J. Synth. Org. Chem. Jpn., 53, 172 (1995).

5. N. Yonezawa, S. Mori, S. Miyata, Y. Ueha-Anyashiki, and K. Maeyama, React. Funct. Polym., 53, 11 (2002).

6. M. Bochmann and K. Kelly, J. Chem. Soc., Chem. Commun., 532 (1989).

7. M. Rehahn, A.-D. Schlueter, and G. Wegner, Makromol. Chem., Rapid Commun., 11, 535 (1990).

8. J. S. Moore, Makromol. Chem., Rapid Commun., 13, 91 (1992).

9. M. Bochmann and J. Lu, J. Polym. Sci., Part A: Polym. Chem., 32, 2493 (1994).

10. N. Yonezawa, S. Miyata, T. Nakamura, S. Mori, Y. Ueha, and R. Katakai, Macromolecules, 26, 5362 (1993).

11. N. Yonezawa, S. Miyata, S. Mori, Y. Ueha-Anyashiki, S. M. Wu, and K. Maeyama, Polym. J., 35, 998 (2003).

12. N. Yonezawa, T. Namie, T. Ikezaki, H. Hino, H. Nakamura, Y. Tokita, and R. Katakai, React. Funct. Polym., 30, 261 (1996).

13. N. Yonezawa, T. Ikezaki, H. Nakamura, and K. Maeyama, Macromolecules, 33, 8125 (2000).

14. K. Maeyama, S. Sekimura, M. Takano, and N. Yonezawa, React. Funct. Polym., 58, 111 (2004).

15. K. Maeyama, T. Kinuno, T. Jobashi, and N. Yonezawa, React. Funct. Polym., in press.

16. P. E. Eaton, G. R. Carlson, and J. T. Lee, J. Org. Chem., 38, 4071 (1973).

17. N. Miyaura and A. Suzuki, Chem. Rev., 95, 2457 (1995).

18. M. Ueda and M. Sato, Macromolecules, 20, 2675 (1987).

19. M. Ueda and M. Oda, Polym. J., 21, 673 (1989).

20. K. Maeyama, T. Namie, H. Nakamura, and N. Yonezawa, Recent Prog. Polycondens., 173 (2002).

21. N. Yonezawa, H. Nakamura, and K. Maeyama, React. Funct. Polym., 52, 19 (2002).

22. N. Yonezawa, H. Nakamura, T. Ohe, and K. Maeyama, Synth. Commun., in press.

23. K. Maeyama, T. Ohe, H. Nakamura, and N. Yonezawa, Polym. J., 35, 290 (2003).

24. K. Maeyama, T. Ohe, H. Nakamura, and N. Yonezawa, Polym. J., 35, 1009 (2003). 